\title{
Evaluation Of The Design Of Auxiliary Equipment At The Back Printing Station With Ergonomic Approach
}

\author{
Fahmi Fathurrahman \\ Department Of Industrial Engineering, University Of North Sumatra, Jl. Dr. Mansur No. 9 Padang Bulan, Kec. \\ Medan Baru, Kota Medan 20222
}

\begin{tabular}{|c|c|}
\hline ARTICLE INFO & ABSTRACT \\
\hline Article history: & \multirow{3}{*}{$\begin{array}{l}\text { Ngatiyem refinery is a small and medium enterprise that produces } \\
\text { bricks. This business was founded in } 2005 \text { which is located in } \\
\text { Jatimulyo village, Perbaungan district, Deli Serdang regency, North } \\
\text { Sumatra province. The process of making bricks is carried out for } 8 \\
\text { hours every day with } 12 \text { workers and produces } 15,000 \text { bricks. The } \\
\text { problem faced by the company is that activities at the printing station } \\
\text { experience problems with working postures for operators who are } \\
\text { not ergonomic so that it can cause MSDs, operators become tired } \\
\text { quickly, complaints of work-related illnesses are high and errors } \\
\text { often occur in work. The purpose of this research is to improve the } \\
\text { facilities used in order to simplify and reduce existing obstacles. With } \\
\text { the design of the tool design, it is expected to be able to overcome } \\
\text { the problems faced by the company so that the products produced } \\
\text { are getting better and increasing in quantity. The results of the REBA } \\
\text { (Rapid Entire Body Assessment) data processing show that activities } \\
\text { at the stone molding station must be repaired as soon as possible to } \\
\text { reduce the existing problems. }\end{array}$} \\
\hline $\begin{array}{r}\text { Received Feb 05, } 2020 \\
\text { Revised Mar 13, } 2020 \\
\text { Accepted Apr 30, } 2020\end{array}$ & \\
\hline $\begin{array}{r}\text { Keywords: } \\
\text { Worker Complaints } \\
\text { Workload } \\
\text { Work Posture } \\
\text { Application Of Assitive Devices }\end{array}$ & \\
\hline
\end{tabular}

This is an open access article under the CC BY-NC license.

\section{Corresponding Author:}

Fahmi Fathurrahman,

Department Of Industrial Engineering,

University Of North Sumatra,

Jl. Dr. Mansur No. 9 Padang Bulan, Kec. Medan Baru, Kota Medan 20222.

Email : fahmi001@gmail.com

\section{INTRODUCTION}

Small and medium enterprises are an important part of the economy of a country or region, including in Indonesia which includes several fields such as manufacturing, trading and those that produce services.

Ngatiyem refinery is a small and medium enterprise that produces bricks. This business was founded in 2005 which is located in Jatimulyo village, Perbaungan district, Deli Serdang regency, North Sumatra province. The process of making bricks is carried out for 8 hours every day with 12 workers and produces 15,000 bricks. Brick making is done at 6 stations, namely manual mixing stations, machine mixing, molding, drying, burning, and storage. Activities at the printing station experience problems with working postures for operators who are not ergonomic so that it can cause MSDs, operators become tired quickly, complaints of work-related illnesses are high and errors often occur in work. 
The printing of bricks is carried out by two operators, where the printing process begins with the second operator taking an empty pallet from the cart located in front of the printing machine and placing it into the printing machine. The 1st operator starts to print the bricks by pulling the lever of the machine. The printed bricks will be sprinkled with sawdust/sand on top by the 1st operator, then operators 1 and 2 lift the brick pallet to the cart.

The process of lifting and moving bricks is done manually with a total load of $24 \mathrm{~kg}$ consisting of $21 \mathrm{~kg}$ bricks and $3 \mathrm{~kg}$ pallets. These activities still use tools that do not consider ergonomics so that it can cause MSDs (Musculoskeletal Disorders).

Wakhid (2012) researched on oil palm transportation activities using REBA and Cardiovascular Load (\%CVL) methods. Problems with oil palm transportation activities carried out by operators can cause injuries and diseases to the spine. Based on the REBA method used, it shows that in the activity of transporting oil palm fruit to the assessment of work posture, a score of 8 is obtained, which means it is included in the category of immediate repair to reduce the risk of injury. Based on the calculation of \%CVL obtained by the load on the operator, $46.97 \%$ is included in the repair interval, based on existing references the researcher determines the title of the final project to be carried out is the evaluation of the design of tools at the brick molding station with an ergonomic approach.

\section{RESEARCH METHOD}

The type of research used is the type of experimental research. This experimental research aims to find a causal relationship between the factors that are intentionally caused by eliminating or reducing other disturbing factors. Experimental research aims to investigate a causal relationship and how big the relationship is by applying treatment to one or more experimental groups and comparing the results with one or more control groups (Sinulingga, 2011).

In this section, an analysis of the comparison of operator complaints is carried out, an analysis of the operator's work posture and an analysis of the work facilities used by comparison before and after the application of the tool.

The last step is drawing conclusions that contain important points in this study. The conclusion is a summary formulation of the research results, while the suggestions given will be directed at several designs or suggestions for improvements that are beneficial for the company and for subsequent studies.

\section{RESULTS AND DISCUSSIONS}

\subsection{Complaint Rate Analysis}

\section{a. Operator Complaints before Using the Tool}

Standard Nordic Quistionnaire (SNQ) shows that operators at brick-making stations are more dominant in the sick and very sick categories. Operator 1 pain category is in the left and right shoulder, back, left and right forearm, while in the very sick category there is left and right upper arm, left and right hand. Operator pain category 2 is in the left and right upper arms, back, left and right elbows, left and right wrists, left and right right hands. Complaints occur because the operator still has to lift a pallet filled with bricks for 8 hours / day.

SNQ on brick delivery operators showed that sick and very sick categories were more dominant, especially in the hands and feet used to push carts filled with pallets with bricks.

\section{b. Operator Complaints after Using the Tool}

Standard Nordic Quistionnaire (SNQ) after using the design of the tool the very sick category did not occur and the pain category was only experienced by operator 1 on the left and right upper arms, and back. The use of this tool reduces complaints of pain to the operator so that it is easier to carry out the process of moving bricks where the operator only shifts the pallet to the cart without having to lift it.

SNQ on delivery operators shows a decrease in the sick category due to changes in cart design and by using lighter materials than the previous one 


\subsection{Workload Analysis}

\section{a. Operator Workload before Using the Tool}

The percentage of Cardiovascular Load operators before using assistive devices reaches $>30 \%$ so that in this percentage category improvements are needed to reduce the workload received by the operator. The largest percentage is received by operator 1 at the printing station who is also in charge of pulling the lever of the printing machine. The smallest percentage is received by Operator 2 at the printing station. The following is a recapitulation of the percentage of operators of molding and brick delivery stations shown in table 1.

Table 1. Recapitulation of \%CVL Before Using Tools

\begin{tabular}{ccc}
\hline Criteria & Percentage of Cardiovascular Load (CVL) \\
\hline Printing Station & Operator 1 & $34.95 \%$ \\
& Operator 2 & $31.19 \%$ \\
& Operator 1 & $34.61 \%$ \\
Introduction & Operator 2 & $34.34 \%$ \\
\hline
\end{tabular}

\section{b. Operator Workload after Using Assistive Tools}

The percentage of Cardiovascular Load operator after using the assistive device decreased $<30 \%$ so it can be concluded that the repair of the assistive device is very helpful for the operator in doing the job. The largest percentage is received by the 2 brick delivery operators. The smallest percentage is received by the operator of the 2 printing stations. The recapitulation can be seen in table 2 below.

Tabel 2. \%CVL Recapulation After Using the Tool

\begin{tabular}{ccc}
\hline Criteria & \multicolumn{2}{c}{$\begin{array}{c}\text { Percentage of Cardiovascular Load } \\
\text { (CVL) }\end{array}$} \\
\hline Printing & Operator 1 & $25.24 \%$ \\
Station & Operator 2 & $23.85 \%$ \\
& Operator 1 & $24.61 \%$ \\
Introduction & Operator 2 & $28.28 \%$ \\
\hline
\end{tabular}

\subsection{Work Posture Analysis}

\section{a. Operator Work Posture before Using Assistive Tools}

The elements of the actual movement of labor at the printing station are mostly done with unnatural and non-ergonomic work postures. From the results of the assessment using the REBA method, it can be seen that there are several complaints that occur in several elements of the movement.

1) Movement element pulls the lever to the right

The conclusion of the work posture action for this movement element is that it needs immediate action. This is because operator 1 pulls the lever with a weight of $\pm 20 \mathrm{Kg}$ with a body position of $20^{\circ}-60^{\circ}$

2) Back pull lever movement element

The conclusion of the work posture action for this movement element is that action is needed. This is because the operator only pulls the lever to return the machine position and produces a stone mold with a bent leg position of $30^{\circ}-60^{\circ}$ and upper arm $45^{\circ}-90^{\circ}$

3) Movement elements lifting and stacking stone pallets from molding machines to carts The conclusion of the work posture action for this movement element is that it needs immediate action. This is because the operator lifts a load of $24 \mathrm{Kg}$ with a body bent 20 , legs bent $30-60$.

\section{b. Operator Work Posture after Using Assistive Devices}

The movement element in the repair condition is a change in the work system at the printing station. From the results of the assessment using the REBA method, it can be seen that there are several complaints that occur in several elements of the movement. 
1) Movement element pulls the lever to the right

The conclusion of the work posture action for this movement element is that it needs immediate action. This is because operator 1 pulls the lever with a weight of $\pm 20 \mathrm{Kg}$ with a body position of $20^{\circ}-60^{\circ}$

2) Back pull lever movement element

The conclusion of the work posture action for this movement element is that action is needed. This is because the operator only pulls the lever to return the machine position and produces a stone mold with a bent leg position of $30^{\circ}-60^{\circ}$ and upper arm $45^{\circ}-90^{\circ}$

3) Movement element shifting pallet to cart

The conclusion of the work posture action for this movement element is that it may need action. This is because the operator only shifts load $24 \mathrm{Kg}$ to the cart and no need to bend down and legs bent

\subsection{Analysis Tool}

The tools at the brick molding station are wheelbarrows. The wheelbarrow serves to lighten the operator's workload when moving the bricks to the drying station. The cart is made of hollow iron material but is sturdy and lighter than the previous cart. The advantages of this design eliminate pallet lifting activities on the cart so that the moving process becomes faster. The old work system requires 2 operators while the new work system only uses 1 operator in the brick making process. The drawback of this design is that the delivery operator has to adapt to the new work system due to the additional rollers that must be raised when stacking the stone pallets to the cart and lowered before delivering the stone pallets. Operators at the drying station also have to adapt when picking and placing pallets because of the roller covering the top of the cart so that placing and picking up can only be done through the space in front of the cart which is quite small and can only load 4 pallets. To overcome the existing obstacles, the operator can place the pallet and the remaining bricks on the roller cart as during the initial delivery so that the operator's work will become easier. The tools that have been applied to the Ngatiyem Refinery business can be seen in Figure 6.1 To overcome the existing obstacles, the operator can place the pallet and the remaining bricks on the roller cart as during the initial delivery so that the operator's work will become easier. The tools that have been applied to the Ngatiyem Refinery business can be seen in Figure 6.1 To overcome the existing obstacles, the operator can place the pallet and the remaining bricks on the roller cart as during the initial delivery so that the operator's work will become easier. The tools that have been applied to the Ngatiyem Refinery business can be seen in Figure 1.

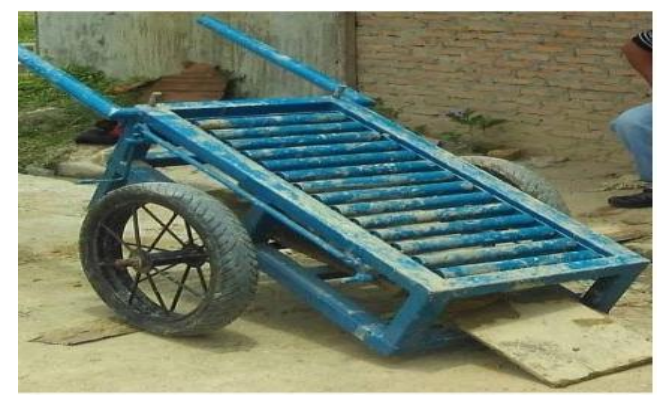

Figure 1. Wheelbarrow Auxiliary Tool

\section{CONCLUSION}

Results application design tool help could lower complaint Musculos keletal disorders (MSDs) on the print operator.

The results of the Standard Nordic Questionnaire (SNQ) assessment show that by using the design of the tool the complaints felt by the operator are reduced for the better.

Assessment of Work Posture by using REBA at the time after the application of the tool shows that the operator's working posture becomes better and reduces the burden of lifting stones. 
In calculating the pulse rate using the Automatic Blood Pressure Monitor, a significant decrease in the percentage of Cardiovascular load is seen

\section{REFERENCES}

E. Nurmianto, Ergonomi, Konsep Dasar dan Aplikasinya, Surabaya: PT. Guna Widya, 1996

Agil, Fitra. Rancangan Fasilitas Kerja Pada Stasiun Pencetakan Di UKM Gunung Jati, Universitas Sumatera Utara, 2015

Kurnianingtyas, C.D., Perbaikan Fasilitas Kerja Pada Aktivitas Penghalusan Kayu Untuk Memperbaiki Postur Kerja Di Industri Kerajinan Mainan Anak- anak, Universitas Atmajaya Yogyakarta, 2015

Middlesworth, Mark, A Step by Step Guide Rapid Entire Body Assessment (REBA). Ergonomics Plus Inc, www.ergo-plus.com, 2014

Mutia, Mega, Pengukuran Beban Kerja Fisiologis dan Psikologis pada Operator Pemetikan the dan Operator Produksi The Hijau di PT Mitra Kerinci, Universitas Andalas Padang, 2014

S.H. Tarwaka, A. Bakri dan L. Sudiajeng, Ergonomi Untuk Kesehatan dan Keselamatan Kerja dan Produktivitas, Surakarta: UNIBA Press, 2004

Sinulingga, Sukaria., Metode Penelitian, Edisi Pertama, Medan: USU Press, 2011. Usaha Kilang Ngatiyem

Wakhid Muhammad, Analisis Postur Kerja Pada Aktivitas Pengangkutan Buah Kelapa Sawit Dengan Menggunakan Metode Rapid Entire Body Assesment (REBA), Fakultas Teknik Universitas Dian Nuswantoro Semarang, 2012 